\title{
FELT JOB INSECURITY AND UNION MEMBERSHIP: THE CASE OF TEMPORARY WORKERS
}

Nele DE CUYPERa, Hans DE WITTEa,b, Magnus SVERKEb,c, Johnny HELLGRENc, Katharina NÄSWALLc,d

a Research Group Work, Organization and Personnel Psychology, KU Leuven, Belgium

b North-West University, South Africa

c Department of Psychology, Stockholm University, Sweden

d University of Canterbury, New Zealand

UDK: 331.105.2-057.117:331.105.44

Izvorni znanstveni rad

Primljeno: 13. 1. 2014

The present study investigates the relationship between felt job insecurity and union membership accounting for potential differences between temporary and permanent workers. Consistent with the idea that felt job insecurity leads workers to seek social protection from the unions, and with earlier studies, we hypothesize a positive relationship between felt job insecurity and union membership (Hypothesis 1). Furthermore, we argue that this relationship may be stronger among temporary compared with permanent workers (Hypothesis 2): insecure temporary workers are in a situation of 'double vulnerability', hence they have strong motives for unionization. Hypotheses are tested in a cross-sectional sample of 560 Flemish (Dutch-speaking part of Belgium) workers. Our results were as follows: the relationship between felt job insecurity and union membership was not significant. The interaction term between contract type and felt job insecurity was significantly related to union membership: the relationship between felt job insecurity and union membership was positive among temporary workers, but not among permanent workers. This pattern of results may inspire unions to target future recruitment strategies on temporary workers. A route for future research could be to test our hypotheses also longitudinally.

Keywords: contingent employment, fixed-term employment, job insecurity, social protection, union Personnel Psychology, KU Leuven, Tiensestraat 102 (pb 3725), 3000 Leuven, Belgium.

E-mail: nele.decuyper@ppw.kuleuven.be 
Antecedents of union membership have been sought at different levels: economic (e.g., unemployment rate), institutional (e.g., union-affiliated unemployment benefits), personal (e.g., age, occupational position) and psychological (Stinglhamber, Gillis, Teixeira, \& Demoulin, 2013). Psychological studies have mostly taken the perspective that unionization is a way to voice dissatisfaction with existing working conditions (Bamberger, Kluger, \& Suchard, 1999; Buttigieg, Deery, \& Iverson, 2007; Johnson \& Jarley, 2004). A particular cause for dissatisfaction in today's work environment and one that has traditionally been considered a concern promoting union membership is felt job insecurity (Sverke \& Hellgren, 2001; Waddington \& Whitston, 1997). Felt job insecurity concerns the employee's perception and concern about potential involuntary job loss (De Witte, 1999, 2005; Sverke, Hellgren, \& Näswall, 2002; Vander Elst, De Witte, \& De Cuyper, 2013). Workers who fear they might lose their job may turn to the union to seek social support and protection.

Previous studies have established a positive association between felt job insecurity and union membership (e.g., Allvin \& Sverke, 2000; Bender \& Sloane, 1999; Nätti, Happonen, Kinnunen, \& Mauno, 2005; Sverke et al., 2004). We will take these studies one step further by accounting for type of contract, temporary versus permanent employment in particular. Temporary employment refers to 'dependent employment of limited duration' (OECD, 2002, p. 170), for example in the form of fixed-term employment (for an overview, see De Cuyper et al., 2008). We believe the issue of temporary employment in union research requires more specific attention as temporary workers have strong motives for union membership: temporary workers are generally more insecure than permanent workers (De Cuyper \& De Witte, 2006, 2007), and they may lack other forms of social support at work as they relatively often change employers. Accordingly, a plausible assumption is that the relationship between felt job insecurity and union membership is particularly strong among temporary compared to permanent workers. Surprisingly, temporary employment has not yet attracted much attention in the realm of union research: earlier studies have mostly focussed upon permanent workers (Goslinga \& Sverke, 2003), thereby largely excluding temporary workers from the analyses (Bender \& Sloane, 1999).

In response, it is the intent of this study to investigate the relationship between felt job insecurity and union membership among temporary and permanent workers from two sectors in Flanders, Belgium. Results are based on cross-sectional data. From a practitioners' point of view, our findings may 
help to understand the challenges the union is facing: dealing with increasing levels of felt job insecurity against the background of a growing number of temporary workers.

\section{JOB INSECURITY AND UNION MEMBERSHIP}

The dominant view is that job insecurity may elicit and strengthen union membership. The main argument is that potential and current union members seek social protection. Social protection should be understood broadly in terms of preventing and managing situations that may adversely impact the workers' well-being (United Nations Research Institute for Social Development, 2010), implying also protection against job loss. In this respect, the protection of workers against job loss is central to employees' decision to unionize and to stay unionized (Barling, Fullager, \& Kelloway, 1992; Gallagher \& Strauss, 1991; Stingelhamber et al., 2013; Sverke \& Hellgren, 2001; Waddington \& Whitston, 1997).

This view aligns with the frustration-aggression thesis that explains union membership as a function of employees' frustration with dissatisfying working conditions (Bryson, Cappellari, \& Lucifora, 2004; Hammer \& Avgar, 2005; Nätti et al., 2005; Sverke et al., 2004) and their need to voice their frustration (Sverke \& Hellgren, 2001).

Furthermore, it finds support in earlier studies. Direct evidence comes from studies that have established a positive relationship between felt job insecurity and union membership (e.g., Allvin \& Sverke, 2000; Bender \& Sloane, 1999; Nätti et al., 2005; Sverke et al., 2004), though some exceptions exist (Hartley, Jacobson, Klandermans, \& Van Vuuren, 1991). Indirect evidence comes from the observation that felt job insecurity feeds pro-union attitudes (Sverke \& Goslinga, 2003; Sverke et al., 2004) and reduces turnover from the union (Sverke \& Goslinga, 2003; Sverke et al., 2004). In line with the dominant view and evidence to date, our hypothesis is as follows:

H1: Felt job insecurity relates positively to union membership.

\section{THE CASE OF TEMPORARY WORKERS}

Most research has concerned the situation of permanent workers, while the relationship between felt job insecurity and union membership may be different for temporary workers. Arguments for the differential relationships are plenty, and they fall in two categories, depending on whether the relationship is assumed weaker of stronger.

To begin with, felt job insecurity may not be a cause for unionization among temporary workers to the same extent as 
DRUŠ. ISTRAŽ. ZAGREB GOD. 23 (2014), BR. 4, STR. 577-591

DE CUYPER, N. ET AL.: FELT JOB INSECURITY.. it is among permanent workers. One reason is that temporary workers may fear that unionization reduces future prospects in the organization based on the idea that employers are more likely to hire non-unionized workers or may discriminate union members when hiring new personnel (for a discussion, see e.g., Cooke, 1985). Many temporary workers see their assignment as a stepping stone to permanent employment (De Cuyper \& De Witte, 2008), and they may more easily gain a permanent job through individualistic actions that please the employer, for example excellent performance, citizenship and impression management. Another reason is that temporary workers, unlike permanent workers, may not see job insecurity as a breach of the psychological contract they have with the employer. Instead, they see job insecurity as part of the deal (De Cuyper \& De Witte, 2006, 2007; Klandermans, Klein Hesselink, \& Van Vuuren, 2010). Accordingly, temporary workers may not feel the need to turn to the union in the face of job insecurity. In line with this reasoning, previous studies have demonstrated that felt job insecurity does not relate (as strongly) to strain among temporary workers (compared with permanent workers) (Bernhard-Oettel, Sverke, \& De Witte, 2005; De Cuyper \& De Witte, 2006, 2007; De Witte \& Näswall, 2003; Klandermans et al., 2010; Mauno, Kinnunen, Mäkikangas, \& Nätti, 2005). Hence, frustration with job insecurity may not be the driving force for unionization among temporary workers, while it is among permanent workers.

Alternatively, felt job insecurity may relate more strongly to unionization among temporary compared with permanent workers. First, temporary workers are in a notoriously weaker position to voice their insecurity concerns: they may not know the organizational procedures to address their concerns, they may not have sufficiently strong professional networks in the organization and feel isolated, or they may be afraid of possible reprimands. Accordingly, they may see the union as a way to voice their opinions and strengthen their position though in a more anonymous way. This aligns with the frustration-aggression thesis (Bryson et al., 2004; Hammer \& Avgar, 2005; Nätti et al., 2005; Sverke et al., 2004): union membership is the result of individual's frustration, dissatisfaction or alienation at work. Second, Belgian unions are involved in the administration of unemployment insurances, which may be appealing particularly for job insecure temporary workers: they face 'double' vulnerability (i.e., insecurity and temporarily employed) and may want to anticipate job loss. 
DRUŠ. ISTRAŽ. ZAGREB GOD. 23 (2014), BR. 4 STR. 577-591

DE CUYPER, N. ET AL. FELT JOB INSECURITY..

METHOD

Data Collection
We follow this last line for two reasons. First, it ties in with our earlier argument that seeking social protection is an important motive for unionization. Seeking social protection is particularly relevant for temporary workers: they do not have a broad social network within the organization. Second, empirical evidence seems to support the idea of a stronger relationship between felt job insecurity and union membership among temporary compared with permanent workers. Nätti et al. (2005) reported a similar interaction effect based on the Finnish Working Conditions Survey for the year 2003. Indirect evidence comes from the study by Furaker and Berglund (2003): temporary workers compared with permanent workers were somewhat more likely to agree that unions are needed. In line with this evidence, our second hypothesis is as follows:

$\mathrm{H} 2$ : The positive relationship between felt job insecurity and union membership is stronger among temporary compared with permanent workers.

Data was collected in divisions of seven Belgian companies within Flanders $(N=567)$ that agreed to participate in a survey on the quality of working life (see Guest, Isaksson, \& De Witte, 2010). Two sectors were selected for this study, namely industry with one large company $(\mathrm{N}=263)$ and retail with six smaller organizations $(\mathrm{N}=304)$. The response rate for the industrial setting was $87.6 \%$ : this organization was highly committed to the research and invested heavily in communication towards employees (e.g., by distributing flyers). Response rates for the retail sector varied between $33 \%$ and $58 \%$ in five out of six organizations. One retail organization did not have a HR department to coordinate data collection, which may explain the lower response rate of $20.8 \%$. Sectors and organizations were recruited for three reasons: possibilities for generalizing findings, number of temporary workers and variation in policies towards temporary employment. Potential respondents were asked to fill out the questionnaire during working time, either during group sessions facilitated by the researchers or individually, or, if preferred, at home. Confidentiality and voluntary participation was stressed, and feedback at the company level was guaranteed.

Agency workers were excluded from the analyses owing to their specific triangular employment relationship and to specific regulations for unionization in the agency sector. More- 
over, the small number of agency workers in our sample did not allow more detailed analyses. This led to a total sample size of 560 respondents.

\section{Respondents}

About one respondent out of three $(\mathrm{N}=189 ; 33.7 \%)$ was temporarily employed on a fixed-term contract. The other respondents were permanently employed on an open-ended contract $(\mathrm{N}=371 ; 66.3 \%)$. This was not representative for the Belgian labour market which has less than ten per cent temporary workers (De Cuyper, De Witte, \& Isaksson, 2005), but instead was the result of the researchers' effort to sample temporary workers. About two respondents out of three were union members ( $\mathrm{N}=188 ; 66.3 \%)$, which is slightly higher than the population percentage $(60 \%$; Sverke et al., 2004).

More females $(\mathrm{N}=358 ; 65.3 \%)$ than males $(\mathrm{N}=190 ; 34.7 \%)$ participated in the study. The majority of the respondents did not follow education beyond high school $(\mathrm{N}=422 ; 75.4 \%)$, which related to the relatively high share of blue-collar workers $(\mathrm{N}=351 ; 65.2 \%)$ compared with white-collar workers $(\mathrm{N}=187 ; 34.8 \%)$ in this study. Mean age of the sample was 35 years $(\mathrm{SD}=10)$, ranging from 18 to 58 years. Mean tenure was 10 years $(S D=9)$, with a variation from 1 month to 39 years. Respondents worked on average 31 hours per week $(\mathrm{SD}=9)$, and roughly half of the respondents worked part-time $(47.7 \%)$.

There were differences between the temporary and the permanent sample. First, temporary workers were more likely to be employed in the retail sector $(64.6 \%)$ than in the industrial sector $(35.4 \%)$. This difference was smaller for permanent workers: $48.2 \%$ versus $51.8 \%$, respectively, $\chi^{2}(1, N=560)$ $=13.39, \mathrm{p}<0.001$. Second, unionization rate was lower among temporary workers $(53.7 \%)$ than among permanent workers $(72.7 \%), \chi^{2}(1, \mathrm{~N}=558)=20.10, \mathrm{p}<0.001$. Third, the temporary sample included relatively more women $(74.3 \%)$ than the permanent sample $(60.8 \%), \chi^{2}(1, \mathrm{~N}=548)=9.80, \mathrm{p}<0.01$. Fourth, more permanent workers $(80.9 \%)$ than temporary workers $(64.6 \%)$ followed higher education, $\chi^{2}(1, N=560)=17.94$, $\mathrm{p}<0.001$. Furthermore, temporary workers $(\mathrm{M}=29$ years; $\mathrm{SD}=9.92$ ) were on average younger than permanent workers $(\mathrm{M}=37$ year; $\mathrm{SD}=9.01), \mathrm{t}(533)=-9.22$, $\mathrm{p}<0.001$, and they had lower organizational tenure (Mtemporary $=3$ year; $\mathrm{SD}=4.53$; $M_{\text {permanent }}=14$ year; SD = 9.10), $\mathrm{t}(552)=-15.16, \mathrm{p}<0.001$. Finally, temporary workers worked fewer hours per week $(M=27$ hours/week; $\mathrm{SD}=12.01)$ than permanent workers $(\mathrm{M}=33$ hours/week; SD = 7.64), $\mathrm{t}(547)=-6.48, \mathrm{p}<0.001$. No such differences between the temporary and the permanent sample were found for occupational position (blue-collar versus white-collar workers), $\chi^{2}(1, \mathrm{~N}=538)=0.42, \mathrm{p}=0.57$. 


\section{Measures}

(1) TABLE 1

Means, standard deviations and correlations between the study variables
In all analyses, we controlled for the following variables: organizational tenure (years), average weekly working hours, gen$\operatorname{der}(0=$ female; $1=$ male $)$ and occupational position $(0=$ blue-collar workers; 1 = white-collar workers). We selected these controls because they are important in relation to union membership (Monnot, Wagner, \& Beehr, 2011) and felt job insecurity (Näswall \& De Witte, 2003). We did not control for age because of its high correlation with tenure $(r=0.70, p<0.01)$. Similarly, we did not control for sector because of its high association with occupational position, $\chi^{2}(1, \mathrm{~N}=538)=233.73$, $\mathrm{p}<0.001$ : the majority of blue-collar workers $(70.7 \%)$ worked in industry, and the large majority of white-collar workers $\mathbf{( 9 8 . 4 \% )}$ in retail. Note, however, that we performed the analyses with different subsets of control variables (e.g., age and sector instead of tenure and occupational position), with essentially the same results.

Union membership was coded 0 for non-members and 1 for members.

Contract type was coded 0 for temporary workers and 1 for permanent workers.

Felt job insecurity was assessed using four items developed by De Witte (2000) and validated by Vander Elst et al. (2013). Sample items were 'I feel insecure about the future of my job' and 'I think I might lose my job in the near future'. Reliability (Cronbach's alpha) was 0.85 .

Information about means, standard deviations and correlations is to be found in Table 1 .

\begin{tabular}{|c|c|c|c|c|c|c|c|c|}
\hline & M & SD & 1 & 2 & 3 & 4 & 5 & 6 \\
\hline \multicolumn{9}{|l|}{ 1. Union membership } \\
\hline 2. Contract type (permanent) & & & $0.19^{* *}$ & & & & & \\
\hline 3. Job insecurity & 2.52 & 0.87 & -0.01 & $-0.37^{* *}$ & & & & \\
\hline 4. Tenure & 9.99 & 9.38 & $0.10^{*}$ & $0.54^{* *}$ & $-0.20^{* *}$ & & & \\
\hline 5. Working hours & 31 & 9.67 & $0.24^{* *}$ & $0.27^{* *}$ & $0.18^{* *}$ & $0.13^{* *}$ & & \\
\hline 6. Gender (male) & & & 0.07 & $0.13^{* *}$ & -0.04 & 0.06 & $0.26^{* *}$ & \\
\hline 7. Occupational position (white & lar) & & -0.08 & -0.03 & $-0.23^{* *}$ & -0.00 & $-0.29 * *$ & $-0.19^{* *}$ \\
\hline
\end{tabular}

Note: Union membership: $0=$ non-member, $1=$ member; Contract type: $0=$ temporary contract, 1 = permanent contract; Gender: $0=$ female, $1=$ male; Occupational position: $0=$ blue-collar worker, $1=$ white-collar worker. ${ }^{*} \mathrm{p}<0.05 ;{ }^{* *} \mathrm{p}<0.01$

\section{Analyses}

We used hierarchical moderator logistic regression to test our hypotheses. The control variables were entered at the first step, contract type in the second step, and felt job insecurity in the 
third step. Finally, we included the interaction term between contract type and felt job insecurity. In doing so, we centred the predictor variables before creating the interaction term. Upon significance, the interaction was plotted.

\section{RESULTS}

(1) TABLE 2

Summary of hierarchical moderator logistic regression analysis: predicting union membership

Table 2 summarizes the results of the hierarchical moderator logistic regression. From the control variables, only weekly working hours was associated with union membership: with each unit increase in weekly working hours, the odds of union membership go up by a multiplicative factor of 1.05 (Table 2, Step 1). Furthermore, permanent compared with temporary workers were about twice as likely to report union membership (Table 2, Step 2).

\begin{tabular}{|c|c|c|c|c|c|c|c|c|}
\hline & \multirow[b]{2}{*}{$\beta$} & \multirow{2}{*}{$\frac{\text { Step } 1}{\operatorname{Exp}(\beta)}$} & \multirow[b]{2}{*}{$\beta$} & $\frac{\text { Step } 2}{\operatorname{Exp}(\beta)}$ & \multirow[b]{2}{*}{$\beta$} & Step 3 & \multicolumn{2}{|r|}{ Step 4} \\
\hline & & & & $\operatorname{Exp}(\beta)$ & & $\operatorname{Exp}(\beta)$ & $\beta$ & $\operatorname{Exp}(\beta)$ \\
\hline Tenure & 0.01 & 1.01 & -0.01 & 0.99 & -0.01 & 0.99 & -0.00 & 1 \\
\hline Working hours & $0.05^{* * *}$ & 1.05 & $0.05^{* * *}$ & 1.05 & $0.04^{* * *}$ & 1.05 & $0.04^{* * *}$ & 1.04 \\
\hline Gender (male) & 0.03 & 1.03 & -0.03 & 0.97 & -0.02 & 0.98 & 0.03 & 1.02 \\
\hline $\begin{array}{l}\text { Occupational position } \\
\text { (white-collar) }\end{array}$ & -0.10 & 0.91 & -0.14 & 0.87 & -0.12 & 0.89 & -0.14 & 0.87 \\
\hline $\begin{array}{l}\text { Contract type } \\
\text { (permanent) }\end{array}$ & & & $0.76^{* * *}$ & 2.15 & $0.80^{* * *}$ & 2.23 & $0.83^{* * *}$ & 2.29 \\
\hline Job insecurity & & & & & 0.04 & 1.04 & 0.28 & 1.32 \\
\hline $\begin{array}{l}\text { Contract type } x \\
\text { job insecurity }\end{array}$ & & & & & & & $-0.46^{*}$ & 0.63 \\
\hline$\chi^{2}$ & $\begin{array}{l}32.76 \\
(4, N=560) \\
p<0.001\end{array}$ & & $\begin{array}{l}9.37 \\
(1, N=560) \\
p<0.01\end{array}$ & & $\begin{array}{l}0.13 \\
(1, N=560) \\
p=0.72\end{array}$ & & $\begin{array}{l}4.57 \\
(1, N=560 \\
p<0.05\end{array}$ & \\
\hline $\mathrm{R}^{2}$ Nagelkerke & 0.09 & & 0.11 & & 0.11 & & 0.12 & \\
\hline
\end{tabular}

Note: Union membership: $0=$ non-member, $1=$ member; Contract type: $0=$ temporary contract, $1=$ permanent contract; Gender: $0=$ female, $1=$ male; Occupational position: $0=$ blue-collar worker, $1=$ white-collar worker. Note: $\beta=\log$ odds; $\operatorname{Exp}(\beta)=$ odds.

Our first hypothesis concerned the association between felt job insecurity and union membership. However, felt job insecurity was not significantly related to union membership, and hence Hypothesis 1 was not supported (Table 2, Step 3).

Hypothesis 2 concerned the interaction between contract type and felt job insecurity in relation to union membership. The interaction term contributed to explaining union membership (Table 2, Step 4). Figure 1 shows that felt job insecurity was positively related to union membership among temporary workers, but not among permanent workers. This supported Hypothesis 2. 
OFIGURE 1

The relationship between job insecurity and union membership for temporary workers and permanent

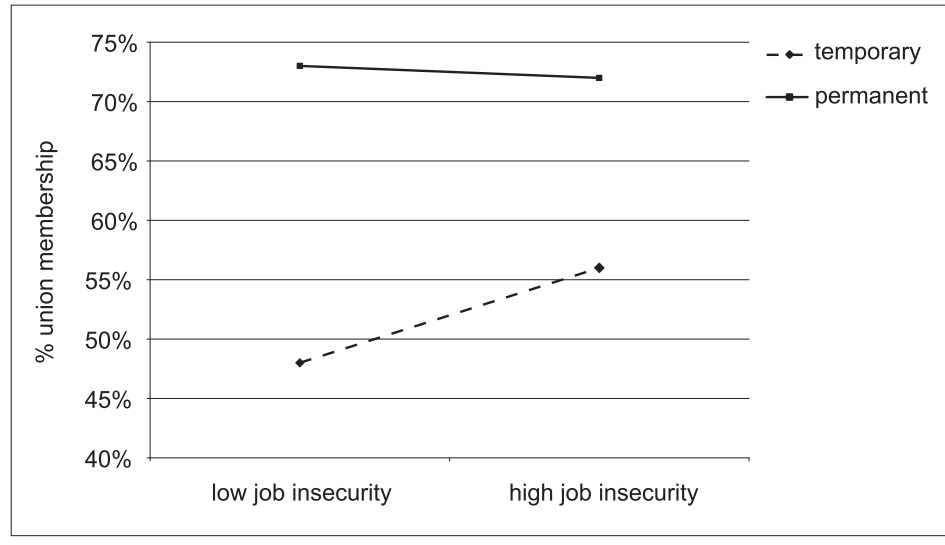

DISCUSSION

Concerns about job insecurity are central to the union's discourse, and scholars have identified felt job insecurity as a motive for joining as well as staying with the union (e.g., Allvin \& Sverke, 2000; Bender \& Sloane, 1999; De Witte et al., 2008; Nätti et al., 2005; Sverke et al., 2004): current and potential union members seek social protection when they anticipate job loss. Accordingly, we hypothesized a positive relationship between felt job insecurity and union membership (Hypothesis 1), but we did not establish this relationship in our sample.

One explanation could be that most workers joined the union early in their career and for reasons other than felt job insecurity: dissatisfaction is generally not the main cause for union membership and participation (Klandermans, 1986). Workers join the union because there is a strong tradition of unionization, for example in Belgium, or because they have instrumental reasons such as representation in collective bargaining or access to extra services such as free legal support in case of disputes and social assistance (Stinglhamber et al., 2013).

While this explanation may apply to permanent workers, unionization at labour market entry is less likely among temporary workers: the union's recruitment efforts are not typically focused upon temporary workers, and temporary workers may not hear about positive union experiences from their colleagues because their networks in the organization are generally weaker (Visser, 1995). This may explain why permanent workers are about twice as likely to be union members (Goslinga \& Klandermans, 2001; Nätti et al., 2005), also in countries with high union density. The implication could be that temporary workers are more actively seeking the union's support on their own initiative, and this may be triggered by 
DRUŠ. ISTRAŽ. ZAGREB GOD. 23 (2014), BR. 4, STR. 577-591

DE CUYPER, N. ET AL.: FELT JOB INSECURITY..

\section{Limitations}

felt job insecurity: temporary workers who feel insecure may hope to find some support to address their precarious situation and they may seek information about unemployment insurance, or anticipate the help unions provide once they are unemployed. Accordingly, a plausible hypothesis is that felt job insecurity relates to union membership among temporary workers but less so among permanent workers (Hypothesis 2), which found support in the study by Nätti et al. (2005) and in the present study: felt job insecurity was positively related to union membership among temporary workers, but not among permanent workers.

The message to unions is that temporary workers are a valuable group to consider for prospective union membership: unionization among temporary workers is relatively low, while at the same time reasons to unionize among temporary workers are strong. Temporary workers may however experience difficulties in finding their way to the union: Belgian unions are represented at the workplace as a means to develop and enhance union commitment through daily contact with union representatives. Temporary workers frequently change jobs or cycle between spells of short-term employment and unemployment, and they are less likely to be integrated in professional networks that favour unionization or share union experiences (Nätti et al., 2005). This presents challenges in the recruitment, organization and representation of temporary workers (Allvin \& Sverke, 2000; Goslinga \& Sverke, 2003; Nätti et al., 2005; Sverke et al., 2004). Furthermore, the voting and election systems tend to exclude temporary workers (Kerkhof, Winder, \& Klandermans, 2005). The implication is that unions may be unaware of the specific needs and concerns of temporary workers, or they may see few incentives to represent temporary workers in collective bargaining.

The results of the present study should be interpreted with a degree of caution and accounting for the following three limitations. First, we used cross-sectional survey data, which obviously limits causal interpretations. We assumed that felt job insecurity 'leads to' union membership, but it could be argued that union membership may also feed feelings of job insecurity: union membership may raise awareness about potential risks related to job insecurity (Sverke et al., 2004). A more provocative idea concerns potential unintended side effects of unionization (Bender \& Sloane, 1999): unions may reduce employment opportunities in the organization by negotiating higher wages, which then may lead to an overall increase in feelings of job insecurity. However, union membership is un- 
DRUŠ. ISTRAŽ. ZAGREB GOD. 23 (2014), BR. 4 STR. 577-591

DE CUYPER, N. ET AL: FELT JOB INSECURITY..

\section{REFERENCES}

likely to be a cause of felt job insecurity among temporary workers: felt job insecurity is inherent to temporary employment. Furthermore, our hypothesis was based on earlier studies on the relationship between felt job insecurity and union membership (Allvin \& Sverke, 2000; Bender \& Sloane, 1999; De Witte et al., 2008; Nätti et al., 2005; Sverke et al., 2004).

Second, some caution is warranted when the aim is to generalize our findings to the Belgian/Flemish population or to other countries. Our sample was not representative for the Belgian/Flemish population. This was related to our strategy of oversampling temporary workers. Moreover, we focussed on the dominant group of fixed-term contract workers in Belgium, and hence we did not account for heterogeneity in temporary contracts. We realize that results may be different among other groups of temporary workers, agency workers or on-call workers, for example. Similarly, results may be conditional upon the unions' recruitment strategies, voting and election systems and organization at the workplace. In this respect, we realize that our arguments may be bound to the Belgian context, with a relatively strong union movement. This is a common problem in the realm of union research. For example, the European and US union literature show some differences based on how unions are organised.

Third, the explained variance was about $12 \%$. This suggests that there are other and potentially more important predictors of union membership. In this respect, Sverke et al. (2004) have highlighted attitudes towards the union (e.g., union satisfaction, union commitment), the job (e.g., job satisfaction) and the organization (e.g., affective organizational commitment). Future research may want to investigate whether these factors are equally important to temporary compared with permanent workers.

Allvin, M., \& Sverke, M. (2000). Do new generations imply the end of solidarity? Swedish unionism in the era of individualization. Economic and Industrial Democracy, 21(1), 71-95. doi:10.1177/0143831X00211004

Bamberger, P. A., Kluger, A. N., \& Suchard, R. (1999). The antecedents and consequences of union commitment: A meta-analysis. Academy of Management Journal, 42(3), 304-318. doi:10.2307/256921

Barling, J., Fullagar, C., \& Kelloway, E. (1992). The union and its members: A psychological approach. New York: Oxford University Press.

Bender, K. A., \& Sloane, P. J. (1999). Trade union membership, tenure and the level of job insecurity. Applied Economics, 31(1), 123-135. doi:10. 1080/000368499324615

Bernhard-Oettel, C., Sverke, M., \& De Witte, H. (2005). Comparing three alternative types of employment with permanent full-time 
DRUŠ. ISTRAŽ. ZAGREB GOD. 23 (2014), BR. 4, STR. 577-591

DE CUYPER, N. ET AL.: FELT JOB INSECURITY.. work: How do employment contract and perceived job conditions relate to health complaints? Work \& Stress: An International Journal of Work, Health \& Organisations, 19(4), 301-318. doi:10.1080/02678370500 408723

Bryson, A., Cappellari, L., \& Lucifora, C. (2004). Does union membership really reduce job satisfaction? British Journal of Industrial Relations, 42(3), 439-459. doi:10.1111/j.1467-8543.2004.00324.x

Buttigieg, D. M., Deery, S. J., \& Iverson, R. D. (2007). An event history analysis of union joining and leaving. Journal of Applied Psychology, 92(3), 829-839. doi:10.1037/0021-9010.92.3.829

Cooke, W. N. (1985). The rising toll of discrimination against union activists. Industrial Relations: A Journal of Economy and Society, 24(3), 421-441.

De Cuyper, N., De Jong, J., De Witte, H., Isaksson, K., Rigotti, T., \& Schalk, R. (2008). Literature review of theory and research on the psychological impact of temporary employment: Towards a conceptual model. International Journal of Management Reviews, 10(1), 25-51. doi:10.1111/j.1468-2370.2007.00221.x

De Cuyper, N., De Witte, H., \& Isaksson, K. (2005). Employment contracts: How to deal with diversity? In N. De Cuyper, K. Isaksson, \& H. De Witte (Eds.), Employment contracts and well-being among European workers (pp. 15-34). Hampshire, UK: Ashgate Publishing.

De Cuyper, N., \& De Witte, H. (2006). The impact of job insecurity and contract type on attitudes, well-being and behavioural reports: A psychological contract perspective. Journal of Occupational and Organizational Psychology, 79(3), 395-409. doi:10.1348/096317905X53660

De Cuyper, N., \& De Witte, H. (2007). Job insecurity in temporary versus permanent workers: Associations with attitudes, well-being, and behavior. Work \& Stress: An International Journal of Work, Health $\mathcal{E}$ Organisations, 21(1), 65-84. doi:10.1080/02678370701229050

De Cuyper, N., \& De Witte, H. (2008). Volition and reasons for accepting temporary employment: Associations with attitudes, well-being and behavioural intentions. European Journal of Work $\mathcal{E}$ Organizational Psychology, 17(3), 363-387. doi:10.1080/13594320701810373 De Witte, H. (1999). Job insecurity and psychological well-being: Review of the literature and exploration of some unresolved issues. European Journal of Work and Organizational Psychology, 8(2), 155-177. doi:10.1080/135943299398302

De Witte, H. (2000). Arbeidsethos en jobonzekerheid: Meting en gevolgen voor welzijn, tevredenheid en inzet op het werk (Work ethic and job insecurity: Measurement and consequences for well-being, satisfaction and performance at work). In R. Bouwen, K. De Witte, H. De Witte, \& T. Taillieu (Eds.), Van groep naar gemeenschap (From group to community). Liber Amicorum Prof. Dr. Leo Lagrou (pp. 325-350). Leuven, Belgium: Garant.

De Witte, H. (2005). Job insecurity: Review of the international literature on definitions, prevalence, antecedents and consequences. Journal of Industrial Psychology, 31(4), 1-6.

De Witte, H. \& Näswall, K. (2003). 'Objective' versus 'subjective' job insecurity: Consequences of temporary work for job satisfaction and 
DRUŠ. ISTRAŽ. ZAGREB GOD. 23 (2014), BR. 4 STR. 577-591

DE CUYPER, N. ET AL. FELT JOB INSECURITY.. organizational commitment in four European countries. Economic and Industrial Democracy, 24(2), 149-188. doi:10.1177/0143831X03024002002

De Witte, H., Sverke, M., Van Ruysseveldt, J., Goslinga, S., Chirumbolo, A., Hellgren, J., \& Näswall, K. (2008). Job insecurity, union support and intentions to resign membership: A psychological contract perspective. European Journal of Industrial Relations, 14(1), 85-103. doi:10.1177/0959680107086113

Furaker, B., \& Berglund, T. (2003). Are the unions still needed? Employees' view of their relations to unions and employers. Economic and Industrial Democracy, 24(4), 573-594. doi:10.1177/0143831X030244005

Gallagher, D. G., \& Strauss, G. (1991). Union membership attitudes and participation. In G. Strauss, D. G. Gallagher, \& J. Fijorito (Eds.), In the state of the union (pp. 139-174). Madison: Industrial Relations Research Association.

Goslinga, S., \& Klandermans, B. (2001). Union participation in The Netherlands: Differences between traditional and 'new' employees. In G. Van Gyes, H. De Witte, \& P. Pasture (Eds.), Can class still unite? The differentiated workforce, class solidarity and trade unions (pp. 171-190). Aldershot: Ashgate.

Goslinga, S., \& Sverke, M. (2003). Atypical work and trade union membership: Union attitudes and union turnover among traditional versus atypically employed union members. Economic and Industrial Democracy, 24(2), 290-312. doi:10.1177/0143831X03024002007

Guest, D. E., Isaksson, K., \& De Witte, H. (Eds.) (2010). Employment contracts, psychological contracts and employee well-being. An international study. Oxford: Oxford University Press.

Hammer, T. H., \& Avgar, A. (2005). The impact of unions on job satisfaction, organizational commitment, and turnover. Journal of Labor Research, 26(2), 241-266. doi:10.1007/s12122-005-1024-2

Hartley, J., Jacobson, D., Klandermans, B., \& Van Vuuren, T. (1991). Job insecurity: Coping with jobs at risk. London: Sage.

Johnson, N. B., \& Jarley, P. (2004). Justice and union participation: An extension and test of mobilization theory. British Journal of Industrial Relations, 42(3), 543-562. doi:10.1111/j.1467-8543.2004.00329.x

Kerkhof, P., Winder, A., \& Klandermans, B. (2005). Job insecurity and works council participation. In H. De Witte (Ed.), Job insecurity, union involvement and union activities (pp. 63-80). Aldershot: Ashgate.

Klandermans, B. (1986). Perceived costs and benefits of participation in union action. Personnel Psychology, 39(2), 379-397. doi:10.1111/j.17446570.1986.tb00588.x

Klandermans, B., Klein Hesselink, D. J., \& Van Vuuren, T. (2010). Employment status and job insecurity: On the subjective appraisal of an objective status. Economic and Industrial Democracy, 31(4), 557-577. doi:10.1177/0143831X09358362

Mauno, S., Kinnunen, U., Mäkikangas, A., \& Nätti, J. (2005). Psychological consequences of fixed-term employment and perceived job insecurity among health care staff. European Journal of Work and Organizational Psychology, 14(3), 209-237. doi:10.1080/13594320500146649 
DRUŠ. ISTRAŽ. ZAGREB GOD. 23 (2014), BR. 4, STR. 577-591

DE CUYPER, N. ET AL.: FELT JOB INSECURITY..
Monnot, M. J., Wagner, S., \& Beehr, T. A. (2011). A contingency model of union commitment and participation: Meta-analysis of the antecedents of militant and non-militant activities. Journal of Organizational Behavior, 32(8), 1127-1146. doi:10.1002/job.736

Näswall, K., \& De Witte, H. (2003). Who feels insecure in Europe? Predicting job insecurity from background variables. Economic and Industrial Democracy, 24(2), 189-215. doi:10.1177/0143831X03024002003

Nätti, J., Happonen, M., Kinnunen, U., \& Mauno, S. (2005). Job insecurity, temporary work and trade union membership in Finland 1977-2003. In H. De Witte (Ed.), Job insecurity, union involvement and union activism (pp. 11-47). Hampshire, UK: Ashgate.

OECD (2002). Employment Outlook. Paris: Organization for Economic Co-operation and Development. doi:10.1787/empl_outlook-2002-en

Stinglhamber, F., Gillis, C., Teixeira, C. P., \& Demoulin, S. (2013). To be or not to be unionized? A question of organizational support and identification. Journal of Personnel Psychology, 12(2), 92-96. doi:10. 1027/1866-5888/a000086

Sverke, M., \& Goslinga, S. (2003). The consequences of job insecurity for employers and unions: Exit, voice and loyalty. Economic and Industrial Democracy, 24(2), 241-270. doi:10.1177/0143831X03024002005

Sverke, M., \& Hellgren, J. (2001). Exit, voice and loyalty reactions to job insecurity in Sweden: Do unionized and non-unionized employees differ? British Journal of Industrial Relations, 39(2), 167-182. doi:10. 1111/1467-8543.00195

Sverke, M., Hellgren, J., \& Näswall, K. (2002). No security: A meta-analysis and review of job insecurity and its consequences. Journal of Occupational Health Psychology, 7(3), 242-264. doi:10.1037/1076-8998. 7.3.242

Sverke, M., Hellgren, J., Näswall, K., Chirumbolo, A., De Witte, H., \& Goslinga, S. (2004). Job insecurity and union membership: European unions in the wake of flexible production. Brussels, Belgium: P.I.E.-Peter Lang.

United Nations Research Institute for Social Development (UNRISD) (2010). Combating poverty and inequality: Structural change, social policy and politics. UNRISD publication. Geneva, Switzerland.

Vander Elst, T., De Witte, H., \& De Cuyper, N. (2013). The Job Insecurity Scale: A psychometric evaluation across five European countries. European Journal of Work and Organizational Psychology. Advance online publication. doi:10.1080/1359432X.2012.745989

Visser, J. (1995). Trade unions from a comparative perspective. In J. Van Ruysseveldt, R. Huiskamp, \& J. van Hoof (Eds.), Comparative industrial and employment relations (pp. 37-67). London: Sage.

Waddington, J., \& Whitston, C. (1997). Why do people join unions in a period of membership decline? British Journal of Industrial Relations, 35(4), 515-546. doi:10.1111/1467-8543.00067 
DRUŠ. ISTRAŽ. ZAGREB GOD. 23 (2014), BR. 4 STR. 577-591

DE CUYPER, N. ET AL. FELT JOB INSECURITY...

\section{Doživljaj nesigurnosti posla i članstvo u sindikatu: slučaj privremenih radnika}

Nele DE CUYPERa, Hans DE WITTEa,b, Magnus SVERKEb,c, Johnny HELLGRENc, Katharina NÄSWALLc,d

a KU Leuven, Belgiija

b Sveučilište North-West, Južna Afrika

c Sveučilište u Stockholmu, Švedska

d Sveučilište Canterbury, Novi Zeland

Ova studija istražuje odnos između doživljaja nesigurnosti posla i članstva u sindikatu, objašnjavajući potencijalne razlike između privremeno zaposlenih radnika i onih u stalnom radnom odnosu. U skladu s tezom da doživliaj nesigurnosti posla navodi radnike da socijalnu zaštitu zatraže od sindikata, a i u skladu s ranijim istraživanjima, postavlia se hipoteza pozitivne povezanosti između doživljaja nesigurnosti posla i članstva u sindikatu (Hipoteza 1). Nadalje, tvrdi se da ova povezanost može biti jača kod privremenih u usporedbi sa stalnim radnicima (Hipoteza 2): nesigurni privremeni radnici nalaze se u položaju "dvostruke ranjivosti", stoga imaju snažne motive za sindikalno organiziranje. Hipoteze su testirane na uzorku poprečnoga presjeka, koji se sastojao od 560 flamanskih radnika (nizozemsko govorno područje u Belgiii). Rezultati su ovakvi: povezanost doživljaja nesigurnosti posla i članstva u sindikatu nije bila značajna. Interakcija između vrste ugovora i doživljaja nesigurnosti posla bila je značajno povezana s članstvom u sindikatu: povezanost doživljaja nesigurnosti posla i članstva u sindikatu bila je pozitivna kod privremenih radnika, ali ne i kod stalnih radnika. Ovakav rezultat može potaknuti sindikate da se ubuduće usmiere prema strategijama privlačenja privremenih radnika. U sljedećim istraživanjima hipoteze bi se mogle testirati i longitudinalno.

Ključne riječi: povremeni rad, rad na određeno vrijeme, nesigurnost posla, socijalna zaštita, sindikat 